\title{
Experimental analysis of growth and survivorship in a marine gastropod aggregation: balancing growth with safety in numbers
}

\author{
Melody Ray, Allan W. Stoner \\ Caribbean Marine Research Center, 805 East 46th Place, Vero Beach, Florida 32963, USA
}

\begin{abstract}
The relative roles of habitat quality and predation were examined to test the hypothesis that survivorship in a marine gastropod, Strombus gigas, is enhanced by living in aggregations when young. Enclosure and tether experiments were conducted in and around a juvenile aggregation located in the middle of a tidal flow field in the Bahamas which occupied ca 21 ha. Eight stations were selected to represent a gradient from bare sand to high seagrass biomass and a transect through the aggregation (inside density $=0.40$ to 0.56 juveniles $\mathrm{m}^{-2}$; outside density $\leq 0.08$ juveniles $\mathrm{m}^{-2}$ ). Seagrass characteristics proved to be poor predictors of habitat suitability in terms of $S$. gigas growth and, compared with the presence of conspecifics, relatively unimportant predictors in terms of shelter from predation. Although growth was $>0.1 \mathrm{~mm} \mathrm{~d}^{-1}$ at all but 2 stations, juveniles ( 60 to $80 \mathrm{~mm}$ shell length) suffered higher proportional mortality when tethered outside the aggregation ( 48 to $100 \%$ ) than inside (18 to $20 \%$ ). Mortality showed a strong negative correlation with wild S gigas density, suggesting that small-scale distribution is greatly influenced by density-dependent phenomena. Presence of conspecifics proved to be an important factor affecting survivorship in seagrass meadows of the Bahamas.
\end{abstract}

KEY WORDS: Strombus gigas - Habitat quality Predation S Seagrass - Tethering - Bahamas

\section{INTRODUCTION}

Seagrass meadows serve as nursery grounds for a host of fish and invertebrate species (Livingston 1984, Bell et al. 1988, Heck et al. 1989, Howard et al. 1989). Frequently, animal abundance in seagrass beds is correlated with certain measures of habitat complexity such as seagrass blade density or biomass, detrital biomass, leaf characteristics, or rhizome structure (Orth et al. 1984, Stoner \& Lewis 1985). In some cases, distribution patterns have been explained by active habitat choice by the subject species (Bell \& Westoby 1986, Stoner \& Waite 1990). Because seagrasses provide resident fauna with shelter, as well as nutrition, the hypothetical distribution based solely upon food distribution is confounded by differential survivorship. Numerous experimental studies have shown that seagrass structure reduces predation rates on invertebrates (e.g. Heck \& Thoman 1981, Heck \& Wilson 1987, Wilson et al. 1990, Smith \& Herrnkind
1992). Risk of predation decreases with size in many invertebrates, and larger individuals often inhabit broader ranges of habitats within nursery grounds (Jory \& Iversen 1983, Pohle et al. 1991, Smith \& Herrnkind 1992).

Risk of predation may also be influenced by densitydependent phenomena. There is a large body of theoretical literature which suggests that aggregated individuals gain safety in numbers and suffer lower predation rates than do lone or randomly distributed individuals (Bertram 1978, Pulliam \& Caraco 1984, Hager \& Helfman 1991). Aggregated distribution in the gastropods Strombus luhuanus (Catterall \& Poiner 1983) and S. gigas (Stoner \& Ray 1993) has been explained on the basis of intraspecific attraction, perhaps as an evolved response to predation.

In this study we examine the relative role of habitat quality and predation in the population distribution of a large, highly aggregated herbivorous gastropod, queen conch Strombus gigas, which is associated with 
seagrass meadows as a juvenile. Because earlier experiments have shown that queen conch juveniles are subject to density-dependent reductions in growth rate (Stoner 1989) and that they sometimes grow well in areas outside nursery aggregations, field experiments were designed to test the hypothesis that aggregation increases survivorship. Growth (as a measure of habitat quality) and survivorship were determined for juvenile conch both within and outside a well studied nursery aggregation in the central Bahamas toward the goal of understanding the underlying processes affecting distribution patterns of this gastropod.

\section{STUDY AREA}

The Exuma Cays island chain comprises more than 100 cays and rocks that extend northwest to southeast in the central Bahamas, dividing Exuma Sound to the east from the Great Bahama Bank to the west (Fig. 1a, b) Water exchange occurs through numerous tidal inlets that separate the islands, creating extensive flow fields on the bank which are occupied by discrete aggregations of juvenile queen conch. Individual nurseries occur in the same general locations year after year (Wicklund et al. 1991. A. W. Stoner unpubl. data) and vary greatly in size, covering surface areas of 0.3 to 132 ha at densities of 0.1 to 2.0 conch $\mathrm{m}^{-2}$ (Stoner et al. 1993).

One such nursery occupies the seagrass (Thalassia testudinum) portion of the Adderly tidal flow field located west of Lee Stocking Island in the southern Exumas. Like most juvenile aggregations in the Exuma Cays, it is located near a large sand bar in shallow water within $5 \mathrm{~km}$ of the Exuma Sound inlet in moderate density seagrass (Stoner \& Waite 1990, Stoner et al. 1993). On the flood tide, oceanic waters flow in an ' $\mathrm{S}$ '-shaped pattern through Adderly Cut, over the aggregation, and westward past Shark Rock (Fig. 1b, c). This particular nursery area has been the subject of intensive study, and conch density, size distribution, and movement patterns, as well as environmental characteristics, have been described in detail (Stoner \& Ray 1993, Stoner et al. 1993).

(c)
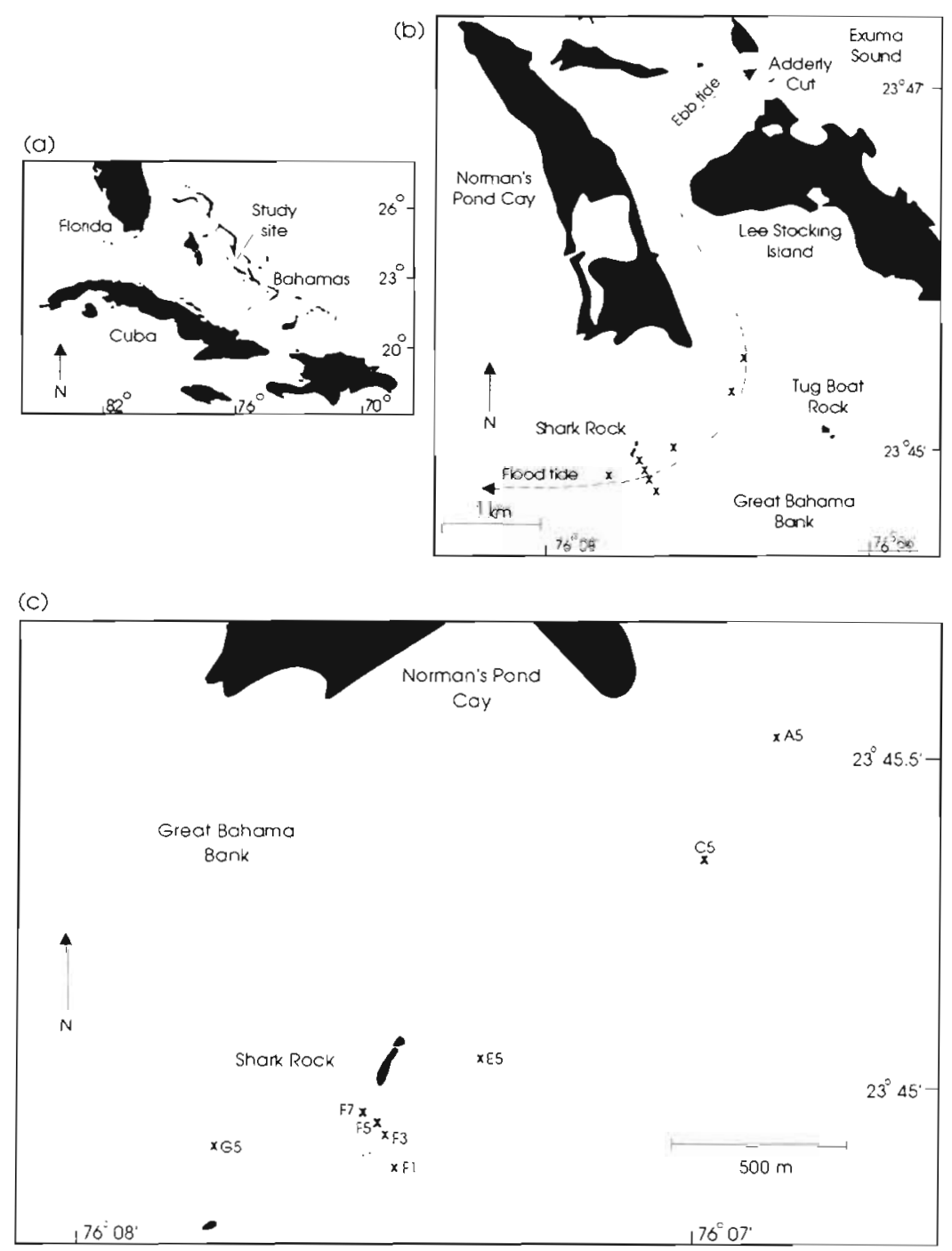

Fig. 1. (a) Study area in the southern Exuma Cays, central Bahamas. (b) Tidal water floods southwest through Adderly Cut past Shark Rock and ebbs northeast. (c) Dotted lines delineate the flow field channel, and shaded areas represent juvenile conch density $\geqslant 0.1$ conch $\mathrm{m}^{-2}$ in June 1991. $\times$ (in $\mathrm{b} \& \mathrm{c}$ ): the 8 experimental stations

The selection of 8 stations for study reflects our intent to examine differential growth and survivorship within and around the nursery area in terms of 2 different perspectives: (1) seagrass structure and (2) the presence or absence of juvenile conch. About $1 \mathrm{~km}$ south of the western point of Lee Stocking Island, the bottom becomes primarily seagrass with highest shoot density and biomass near mid-channel, grading to bare sand on both sides (Stoner \& Ray 1993). Stns F1, F3, F5 \& F7 were located across the flow field, representing the gradient from bare sand (Stn F1) to moderate density seagrass with high green seagrass biomass and high detrital seagrass biomass (Stn F7) (Table 1). In 1988, these 4 stations, in addition to 3 others interspersed 
along the same line, comprised a gradient of Thalassia testudinum from 0 to 851 shoots $\mathrm{m}^{-2}$ through a juvenile conch aggregation (Stoner \& Waite 1990). Stns A5, C5, E5, F5 \& G5 were located down the middle of the flow field through moderate density seagrass. It was our intent that all down-field stations have the same seagrass density, ca 600 to 725 shoots $\mathrm{m}^{-2}$, and that the cross-field stations reflect the seagrass gradient studied previously.

In terms of presence or absence of juvenile conch, station selection also represented perpendicular transects through the juvenile conch aggregation. Preliminary observations in April 1991 showed that the aggregation was continuous and lay between Stns A.5 \& G5. Stns C5 \& F5 represented areas of high conch density inside the aggregation; the 6 other stations (A5, E5, F1, F3, F7 \& G5) were outside the aggregation, representing a range of seagrass characteristics. In June 1991, the aggregation narrowed in the middle forming 2 smaller sub-aggregations.

\section{MATERIALS AND METHODS}

Conch aggregation survey. A density and lengthfrequency survey of the natural conch aggregation was conducted June 3 to 7, 1991. At each station, all conch and potential conch predators (hermit crabs Petrochirus diogenes, apple murex Murex pomum and tulip snails Fasciolaria tulipa; Marshall 1992) were counted within 5 haphazardly placed circles (radius $=4 \mathrm{~m}$ area $=50.3 \mathrm{~m}^{2}$ ). The first 50 conch encountered were measured for shell length (spire to siphonal canal). At each station where conch were sparse, a search was made for additional animals to provide length data.

Juvenile conch aggregations near Shark Rock tend to have boundaries beyond which densities decrease rapidly to zero (Stoner \& Ray 1993). On June 18, 1991 divers were towed systematically over the Shark Rock flow field to estimate the area within which conch were aggregated at a density $>0.1 \mathrm{~m}^{-2}$ (Fig. 1c). The aggregation periphery was buoyed, and buoy positions were determined using a Magellan Nav 1000 GPS (Global Positioning System) unit. All points were plotted on a small-scale map and digitized to calculate surface area occupied by the aggregation.

Enclosure experiments. Juvenile conch were maintained in 2 enclosures at each station from May 24 to August 14, 1991, to monitor growth rate, which is known to be a good indicator of habitat quality (Stoner \& Sandt 1991). Although conch derive most of their carbon from macroalgae and none from living Thalassia testudinum, habitat choice experiments have shown they actively select moderate density $T$. testudinum over low and high densities, and over bare sand (Stoner \& Waite 1990, 1991). Cage locations at each station were selected to represent moderate density seagrass for the down flow field stations and a gradient from bare sand to high density seagrass across the flow field, with minimal intra-station differences.

Table 1 Depth (at mean low water), sediment characteristics, Thalassia testudinum characteristics (shoot count; living, green biomass; detrital biomass), and green, non-calcareous algae biomass, for each station in the Shark Rock study area. All values except depth are mean $\pm \mathrm{SD}$. 1-way ANOVAs were performed on $T$. testudinum shool count and green biomass values; the latter were $\log _{10}$-transformed prior to analysis to improve homogeneity of variance (Cochran's test, $\mathrm{p}>0.05$ ). $F$ and $\mathrm{p}$ values are given, and means that were not different statistically are designated by similar lower-case letters (Tukey HSD multiple comparison test, $p>0.05$ ). Detrital and algal biomass were compared using the Kruskal-Wallis non-parametric test because $\log _{10}$-transformation did not improve heteroscedasticity. Stn F5 data are given twice for comparison in both flow field dimensions

\begin{tabular}{|c|c|c|c|c|c|c|c|c|}
\hline Stn & $\begin{array}{l}\text { Depth } \\
\text { (m) }\end{array}$ & $\begin{array}{l}\text { Mean grain } \\
\text { size }(\phi)\end{array}$ & Sorting & $\begin{array}{l}\text { Organics } \\
\qquad(\%)\end{array}$ & $\begin{array}{l}\text { Shoots } \\
\left(\mathrm{m}^{-2}\right)\end{array}$ & $\begin{array}{c}\text { Green } \\
\left(\mathrm{g} \mathrm{DW} \mathrm{m} \mathrm{m}^{-2}\right)\end{array}$ & 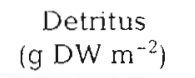 & $\begin{array}{c}\text { Algae } \\
\left(g \mathrm{DW} \mathrm{m}^{-2}\right)\end{array}$ \\
\hline \multicolumn{9}{|c|}{ Down flow field, mid-channel (northeast to southwest) } \\
\hline A.5 & 3.0 & $2.08 \pm 0.06$ & $1.02 \pm 0.08$ & $3.13 \pm 0.14$ & $496 \pm 96$ bc & $43.2 \pm 9.6 \quad a$ & $11.2 \pm 12.8$ & $1.0 \pm 0.8$ \\
\hline C5 & 3.1 & $2.20 \pm 0.06$ & $1.17 \pm 0.01$ & $3.43 \pm 0.13$ & $672 \pm 144 a$ & $70.4 \pm 25.6 \mathrm{~b}$ & $113.6 \pm 94.4$ & $3.2 \pm 3.2$ \\
\hline E5 & 3.2 & $1.74 \pm 0.26$ & $1.24 \pm 0.14$ & $2.98 \pm 0.49$ & $608 \pm 80$ abc & $96.0 \pm 24.0 \mathrm{~b}$ & $99.2 \pm 83.2$ & $105.6 \pm 60.8$ \\
\hline F5 & 2.8 & $2.09 \pm 0.18$ & $1.08 \pm 0.02$ & $2.92 \pm 0.52$ & $704 \pm 160 \mathrm{a}$ & $68.8 \pm 16.0 \mathrm{~b}$ & $129.6 \pm 73.6$ & $0.1 \pm 0.2$ \\
\hline G5 & 2.0 & $2.14 \pm 0.16$ & $0.97 \pm 0.00$ & $2.65 \pm 0.08$ & $448 \pm 96 \mathrm{~cd}$ & $28.8 \pm 9.6 \quad a$ & $11.2 \pm 8.0$ & $70.4 \pm 43.2$ \\
\hline \multicolumn{9}{|c|}{ Cross flow field (south to north) } \\
\hline$F_{1}$ & 1.6 & $1.65 \pm 0.00$ & $0.82 \pm 0.00$ & $1.82 \pm 0.02$ & $4 \pm 16$ & $0.5 \pm 1.6 \mathrm{~d}$ & $0 \pm 0$ & $4.8 \pm 12.8$ \\
\hline F3 & 2.0 & $1.72 \pm 0.13$ & $1.22 \pm 0.05$ & $2.38 \pm 0.10$ & $304 \pm 96 \mathrm{~d}$ & $36.8 \pm 14.4 \mathrm{a}$ & $3.2 \pm 1.6$ & $3.2 \pm 3.2$ \\
\hline F5 & 2.8 & $2.09 \pm 0.18$ & $1.08 \pm 0.02$ & $2.92 \pm 0.52$ & $704 \pm 160 \mathrm{a}$ & $68.8 \pm 16.0 \mathrm{~b}$ & $129.6 \pm 73.6$ & $0.1 \pm 0.2$ \\
\hline \multirow[t]{2}{*}{ F7 } & 3.3 & $1.21 \pm 0.08$ & $1.63 \pm 0.37$ & $3.95 \pm 0.80$ & $640 \pm 96 a b$ & $177.6 \pm 32.0 \mathrm{c}$ & $392.0 \pm 126.4$ & $0.6 \pm 1.6$ \\
\hline & & & & & $\begin{array}{c}F_{(7,56)}=40.39 \\
p<0.001\end{array}$ & $\begin{array}{c}F_{(7,56)}=85.52 \\
p<0.001\end{array}$ & $\begin{array}{l}H=52.97 \\
\mathrm{p}<0.001\end{array}$ & $\begin{array}{l}H=45.31 \\
p<0.001\end{array}$ \\
\hline
\end{tabular}


Cages (height $=0.3 \mathrm{~m}$, diameter $=5 \mathrm{~m}$, area ca $20 \mathrm{~m}^{2}$ ) were constructed from green, plastic-coated wire screen (mesh size $=2.5 \times 5 \mathrm{~cm}$ ) and supported by reinforcement bars driven into the sediment. After all predators and wild conch were removed, 20 tagged conch (95 to $109 \mathrm{~mm}$ ) were placed in each enclosure between 24 and 28 May 1991, creating a density of 1 conch $\mathrm{m}^{-2}$. Initial shell lengths were homogeneous (Cochran's test, $p>0.05$ ) and not significantly different among the stations (1-way ANOVA: $F_{(7.8)}=1.006$, $p=0.490)$. White nylon net $(2 \times 2 \mathrm{~cm}$ mesh) was sewn across the cage tops to exclude predators. Early in this study, strong tidal currents caused severe erosion around the enclosures at sand Stn F1, allowing several conch to escape from cage no. 2. This cage was restocked with new conch on June 5, and a secondary fence was built around both cages to minimize erosion and to prevent predation by tulip snails, which were observed feeding on experimental conch through the wire mesh. Cages were checked periodically to close gaps and keep conch losses at a minimum.

The number of Thalassia testudinum shoots was counted before and after the experiment in each enclosure within 4 quadrats $(25 \times 25 \mathrm{~cm})$ representative of the overall macrophyte cover in the cage area. Also, all seagrasses, macroalgae and detritus (senescent seagrass blades) within the quadrats were collected into $3 \mathrm{~mm}$ mesh nylon bags. Using only above-ground parts, macrophytes were sorted in the laboratory and dried at $80^{\circ} \mathrm{C}$ for approximately $24 \mathrm{~h}$. Dry weight biomass ( $\mathrm{g} \mathrm{m}^{-2}$ ) was determined for living and detrital Thalassia testudinum and for green, non-calcareous algae.

At the beginning of the experiment before conch were added, 1 sediment core sample, $40 \mathrm{~mm}$ in diameter and $5 \mathrm{~cm}$ deep was taken within each cage for analysis of grain size, sorting coefficient, and organic content. Samples were dried at $80^{\circ} \mathrm{C}$ to constant mass, and ca $15 \mathrm{~g}$ were incinerated at $550^{\circ} \mathrm{C}$ for $4 \mathrm{~h}$ to determine organic content, quantified as the percent difference between dry weight and ash-free dry weight. Another sediment subsample was used to determine grain-size characteristics. Sand-sized particles were analyzed using standard dry sieve procedures (Folk 1966). Product-moment statistics were generated for mean grain-size and sortedness according to McBride (1971).

After 5 wk of growth, surviving experimental conch were measured for shell length. Dead or missing conch were replaced with animals in the same size range to maintain density. It was our intent to examine growth of individuals over 2 consecutive periods; replacements added mid-experiment represented a different treatment and were not analysed during the second $5 \mathrm{wk}$ of the experiment. To avoid the problem of pseudoreplication within cages (Hurlbert 1984), the mean grow th rate from each cage was used in the statistical analyses.
After $10 \mathrm{wk}$ of growth, all original conch were again measured for shell length and frozen for condition analysis. After thawing, soft tissue was carefully removed from each shell, blotted dry, and weighed. Gut fullness was subjectively determined on a scale from 0 to 5, empty to greatly distended. Daily shell growth rates during Weeks 0 to 5 and Weeks 5 to 10 and final condition factor [wet weight $(\mathrm{g}) /$ shell length (mm); Stoner \& Waite 1990] were calculated.

Forward stepwise multiple regression (Sokal \& Rohlf 1981) was used to analyze the relationship between growth during both $5 \mathrm{wk}$ periods and Thalassia testudinum shoot density, detritus, biomass, and green algae. In the model, alpha-to-enter and alpha-toremove were both 0.15 ; minimum tolerance for entry was 0.01 .

Tether experiments. Tether experiments were conducted to measure relative predation rates among different habitats. Tethering prevents escape while allowing experimental animals to move and feed within the habitat under investigation [Barshaw \& Able 1990 (American lobster); Wilson et al. 1990 (brachyuran crabs); Heck \& Wilson 1987 (hermit crabs); Marshall 1992, Stoner \& Ray 1993 (conch)]. A comparison of growth rates of tethered conch with free-ranging conch over several weeks showed that tethering did not inhibit growth (Stoner \& Davis 1994).

Each experimental conch was measured and tethered with a white plastic cable-tie fastened around its shell spire and attached to a tether rod with thin monofilament line $(7.5 \mathrm{~kg}$ test, $1 \mathrm{~m}$ long). Tether rods (ca $40 \mathrm{~cm}$ long) were made from stainless steel welding rods which were looped on 1 end, tagged with thin, numbered plastic tags, and pushed into the substrate leaving only the loop and tag visible. Tether rods were spaced $2 \mathrm{~m}$ apart, giving each conch ca $3 \mathrm{~m}^{2}$ of foraging area.

Concurrent with the enclosure experiment, tether experiments were run with 2 different size classes at each of the 8 stations during the summer, when predation rates were presumed highest (Marshall 1992). All juveniles used in this study were collected from aggregations located west of Norman's Pond Cay or south of Lee Stocking Island (Fig. 1b). Small conch were 60 to $80 \mathrm{~mm}$, the smallest wild individuals available in sufficient numbers for the experiment. They were transplanted to the flow field May 1 to 9, 1991 and were monitored for survival 8, 16, 25 and $35 \mathrm{~d}$ after tethering. Large conch, 95 to $109 \mathrm{~mm}$, were transplanted June 11 to 13, immediately after the small conch tethers were retrieved, and monitored at 8,16 , 25, 35 and 50 d. Experimental design was the same for each size class: at each station 40 tethered conch were arranged in 4 blocks of 10 conch, each block running parallel to the axis of the tidal flow field. 
For each size class, initial shell lengths of tethered conch were compared among stations. Data were homogeneous (Cochran's test, $\mathrm{p}>0.05$ ). Small conch at Stn C5 $(73 \pm 4 \mathrm{~mm})$ were slightly larger than the experimental conch at Stn G5 $(70 \pm 4 \mathrm{~mm})$ (1-way ANOVA: $F_{17.310)}=$ 2.206, $p=0.034$; Tukey HSD pairwise comparison test, $p=0.015)$. However, the $3 \mathrm{~mm}$ difference in these 2 means was not deemed biologically significant, and all other stations were similar to one another. Large conch did not vary significantly in shell length among the stations ( 1 -way ANOVA: $F_{(7,312\}}=1.916, \mathrm{p}=0.067$ ).

Another tether experiment was conducted 1 yr later when a change in wild juvenile conch distribution provided the opportunity to examine density-dependent mortality, partially controlled for site. Juvenile conch had consistently occupied Stn F5 in relatively high densities ( 0.26 to 0.69 conch $\mathrm{m}^{-2}$ ) since August 1989, but a survey in January 1992 showed density had substantially decreased to $0.02 \pm 0.01$ conch $\mathrm{m}^{-2}$ (unpubl. data). Using the same block design as earlier, we tethered small conch (60 to $80 \mathrm{~mm}$ ) in May 1992 at Stn F5, from which conch had disappeared, and Stn A5, where they were never observed in abundance.

A tethered conch was considered killed by a predator if the shell was empty, inhabited by a hermit crab, or gone completely, leaving only an empty cable-tie or a severed line. Although the possibility of live conch escaping from or with their tethers cannot be ignored, the method has proven to be reliable (Marshall 1992, Stoner \& Davis 1994). Furthermore, our purpose was to assess relative predation, and the chance of escape was equal among all treatments.

At the end of each tethering experiment all live conch were measured for shell length. All of them or a randomly selected subset of 10 from each station were frozen for condition analysis as described above for caged conch. External damage to empty shells and to those occupied by hermit crabs was recorded.

Variation in tether mortality rate was examined statistically for the first and final observations after the proportions of killed conch per block were arcsinetransformed. Data from an intermediate tether observation during both experiments were also analyzed. This intermediate day was the one on which the first block of tethers at any station reached $100 \%$ mortality; by coincidence, this was the midpoint of the experiment (16 d for small conch and $25 \mathrm{~d}$ for large conch). We considered the rate at which tethered conch died during a limited time period because, if any such experiment is run long enough, all animals will be killed eventually, and their mortality curves will converge at $100 \%$

The Games-Howell multiple comparison test was used to determine pairwise station differences in the mean proportions of dead conch on each date. This parametric test is robust with respect to variance heterogeneity (Day \& Quinn 1989), which occurred in data sets from some dates in spite of arcsine transformations.

Forward stepwise multiple regression was used to analyze the relationship in both size classes between mean mortality and wild conch density, Thalassia testudinum shoot density, detritus, and green biomass for all 8 stations. In the model, alpha-to-enter and alphato-remove were both 0.15 ; minimum tolereance for entry was 0.01 .

\section{RESULTS}

\section{Station characteristics}

Nested ANOVAs performed on Thalassia testudinum shoot counts $\left(F_{(8,48)}=0.645, \mathrm{p}=0.736\right)$, living, green $T$. testudinum biomass $\left(F_{(8,48)}=1.537, \mathrm{p}=0.170\right)$, $T$. testudinum detrital biomass $\left(F_{(8,48)}=1.135, \mathrm{p}=0.357\right)$, and on green, non-calcareous algae $\left(F_{(8,48)}=0.580\right.$, $\mathrm{p}=0.789$ ) showed no intra-station differences. Therefore, the 4 quadrat values taken at the beginning of the experiment from each of the 2 cages were combined to describe the biomass characteristics at each station (Table 1). Nested ANOVAs were again performed on $T$. testudinum shoot counts $\left(F_{(8,48)}=1.739, p=0.113\right)$, green $T$. testudinum $\left(F_{(8,48)}=0.285, p=0.968\right)$, detritus $\left(F_{(8,48)}=0.101, \mathrm{p}=0.999\right)$, and algae $\left(F_{(8,48)}=1.004\right.$, $\mathrm{p}=0.446)$ data collected at the end of the cage experiment, and intra-station differences were not significant.

Stns F1, F3, F5 \& F7 had been selected to represent the cross flow-field gradient from bare sand to high seagrass biomass. Shoot counts and biomass were in fact lowest at Stn F1 and increased towards F5. Although Stns F5 and F7 were similar to each other in terms of shoot counts, green Thalassia testudinum biomass was significantly higher at Stn F7 because of longer blades. Stns A5, C5, E5, F5 \& G5 were selected to represent the longitudinal axis of the flow field through medium density seagrass. Actual quadrat data indicated that the end stations (A5 \& G5) were lower in shoot density and in green and detrital $T$. testudinum biomass than both aggregation centers (Stns C5 \& F5) (Table 1).

Thalassia testudinum detritus was patchy, with at least 3 times more weight occurring at Stn F7 than at any other station (Table 1). Green, non-calcareous algae was also patchy, with at least 14 times more weight occurring at Stns G5 and E5 than at any other station. Depth increased from Stn F1 to Stn F7 and decreased $1 \mathrm{~m}$ between Stns A5 and G5. Sediment grain-size at Stn F7 was the largest and most poorly sorted of all 8 stations. Organic content was highest at Stn F7 and lowest at Stn F1 (Table 1). 


\section{Conch aggregation survey}

In June 1991, the wild juvenile conch aggregation in the Adderly flow field comprised 2 distinct subaggregations (Fig. 1c). One extended from a point south of Stn A5 and ran parallel to the axis of the flow field for about $650 \mathrm{~m}$. This sub-aggregation, with Stn C5 in the center, occupied ca 9.2 ha. The other, located between Stns E5 and G5, occupied ca 12.2 ha. Stn F5 was in the center of the aggregation, Stn $\mathrm{F} 7$ was marginally included within the peripheries and Stn F1 was excluded. The 2 sub-aggregations present in June had, in late April 1991 (unpubl. data), formed 1 continuous population with a constriction near Stn E5.

Relatively high juvenile conch densities ( $\geq 0.40$ conch $\mathrm{m}^{-2}$ ) occurred at Stns C5 \& F5 in 1991 (Table 2). Mean shell length of wild conch at all stations was larger than the largest conch tethered, though conch within the size ranges tethered were present at Stns C5, E5, F5 \& G5. Adults were uncommon, with highest density $\left(<0.02 \mathrm{~m}^{-2}\right)$ at $\mathrm{Stn} \mathrm{F} 7$.

\section{Enclosure experiments}

Growth rates among the 8 stations during both growth periods were significantly different (data were homogeneous (Cochran's test, $p>0.05$ ); 1-way ANOVA: $F_{(7.8)}=8.983, \mathrm{p}=0.003$ (Weeks 0 to 5 ); $F_{(7.8)}=5.771$, $\mathrm{p}=0.012$ (Weeks 5 to 10)] (Fig. 2). In the cross flow field dimension during the first growth period, growth rates peaked at 2 stations with distinctly different Thalassia testudinum characteristics, Stns F3 \& F5 (0.241 and $0.216 \mathrm{~mm}$ of growth $\mathrm{d}^{-1}$ respectively). At Stn F7, where green $T$. testudinum biomass was greatest, mean growth rate during the first growth period (0.121 $\left.\mathrm{mm} \mathrm{d}^{-1}\right)$ was almost an order of magnitude

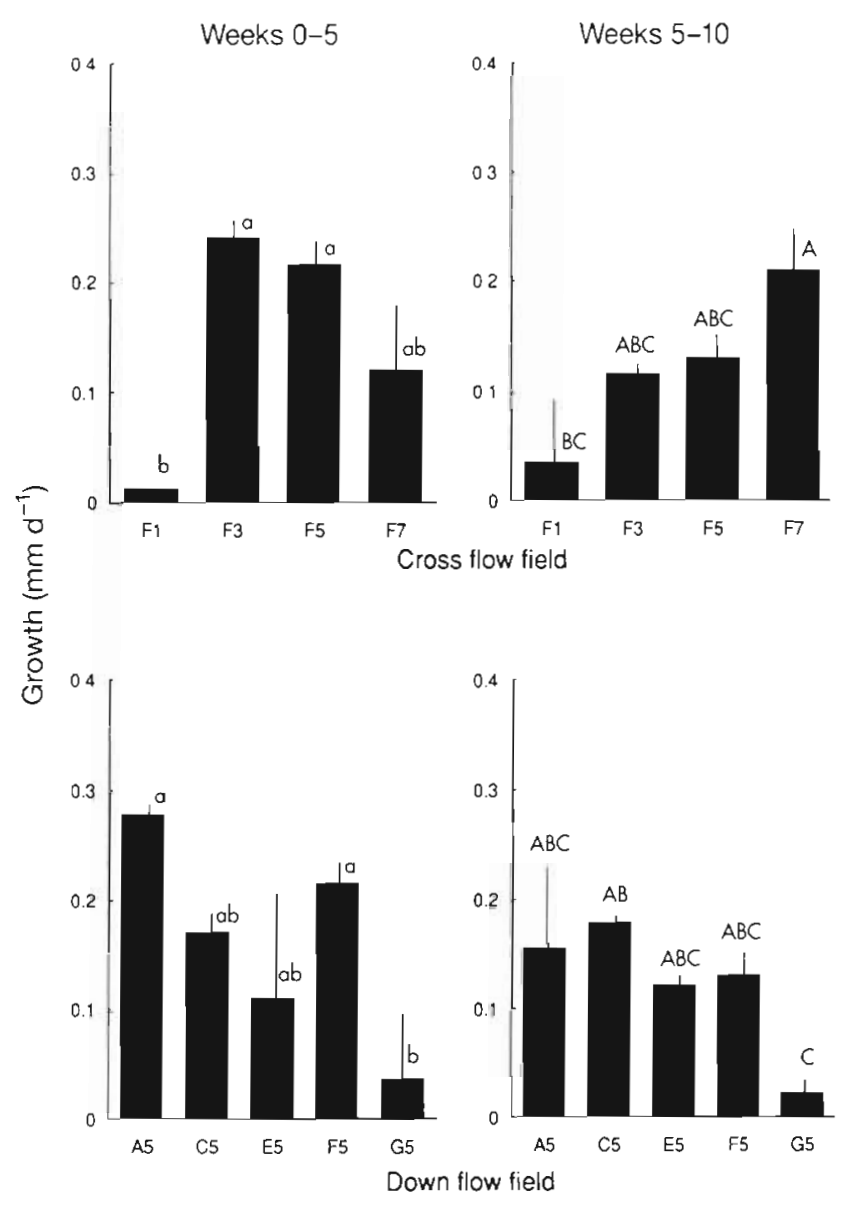

Fig. 2. Strombus gigas. Growth rates of enclosed conch at 8 stations from Weeks 0 to 5 and from Weeks 5 to 10 . Values are mean \pm SD $(\mathrm{n}=2)$. For each 5 wk period, all 8 stations were analysed with 1-way ANOVA (see text for results); means that were not significantly different are designated by similar lower-case letters for Weeks 0 to 5 and by similar upper-case letters for Weeks 5 to 10 (Tukey HSD multiple comparison test, $p>0.05$ ). Stn F5 data are shown twice for comparison in both flow field dimensions

Table 2. Strombus gigas, Petrochirus diogenes, Murex pomum. Mean density of conch, hermit crabs, and apple murex in $50.3 \mathrm{~m}^{2}$ samples and mean length of conch found at each station in June 1991 and at 2 stations in June 1992. Values are mean \pm SD ( $\mathrm{n}$ )

\begin{tabular}{|c|c|c|c|c|c|}
\hline & Station & $\begin{array}{l}\text { Conch } \\
\text { (ind. } \mathrm{m}^{-2} \text { ) }\end{array}$ & $\begin{array}{l}\text { Shell length } \\
(\mathrm{mm})\end{array}$ & $\begin{array}{l}\text { Hermit crabs } \\
\text { (ind. } \mathrm{m}^{-2} \text { ) }\end{array}$ & $\begin{array}{l}\text { Apple murex } \\
\text { (ind. } \mathrm{m}^{-2} \text { ) }\end{array}$ \\
\hline \multirow[t]{8}{*}{1991} & A5 & $0.01 \pm 0.02(5)$ & $183 \pm 14(6)$ & $0.01 \pm 0.01$ & $0 \pm 0(5)$ \\
\hline & C5 & $0.40 \pm 0.19$ & $116 \pm 27(53)$ & $0.76 \pm 0.02$ & $0.02 \pm 0.02$ \\
\hline & E5 & $0.07 \pm 0.08$ & $133 \pm 39(42)$ & $0.06 \pm 0.04$ & $0.01 \pm 0.02$ \\
\hline & F5 & $0.56 \pm 0.44$ & $150 \pm 18(50)$ & $0.02 \pm 0.01$ & $0.02 \pm 0.01$ \\
\hline & G5 & $0.03 \pm 0.03$ & $117 \pm 26(15)$ & $0.01 \pm 0.02$ & $0 \pm 0(5)$ \\
\hline & $\mathrm{F} 1$ & $0 \pm 0(5)$ & none & $0.01 \pm 0.02$ & $0 \pm 0$ \\
\hline & F3 & $0 \pm 0(5)$ & $179(1)$ & $0.07 \pm 0.03$ & $0 \pm 0$ \\
\hline & F7 & $0.08 \pm 0.09(5)$ & $167 \pm 18(50)$ & $0.14 \pm 0.05$ & $0.00 \pm 0.01$ \\
\hline \multirow[t]{2}{*}{1992} & A.5 & $0 \pm 0(4)$ & $196 \pm 8(3)$ & $0.02 \pm 0.04$ & $0 \pm 0(4)$ \\
\hline & F5 & $0.09 \pm 0.07(4)$ & $142 \pm 36(40)$ & $0.02 \pm 0.02$ & $0.01 \pm 0.01$ \\
\hline
\end{tabular}


Fig. 3. Strombus gigas. Cumulative number of (a) small and (b) large conch killed per block of 10 by 3 observation days at 5 stations down the flow field (Stns A5 to G5) and at 4 stations across the seagrass gradient (Stns F1 to F7). Values are mean $\pm S D(n=4)$. For each day, all 8 stations were analysed together: means that were not significantly different are designated by similar lower-case letters (Games-Howell multiple comparison test on arcsine-transformed data, $p>0.05$ ). Stn F5 data are shown twice for comparison in both flow field dimensions
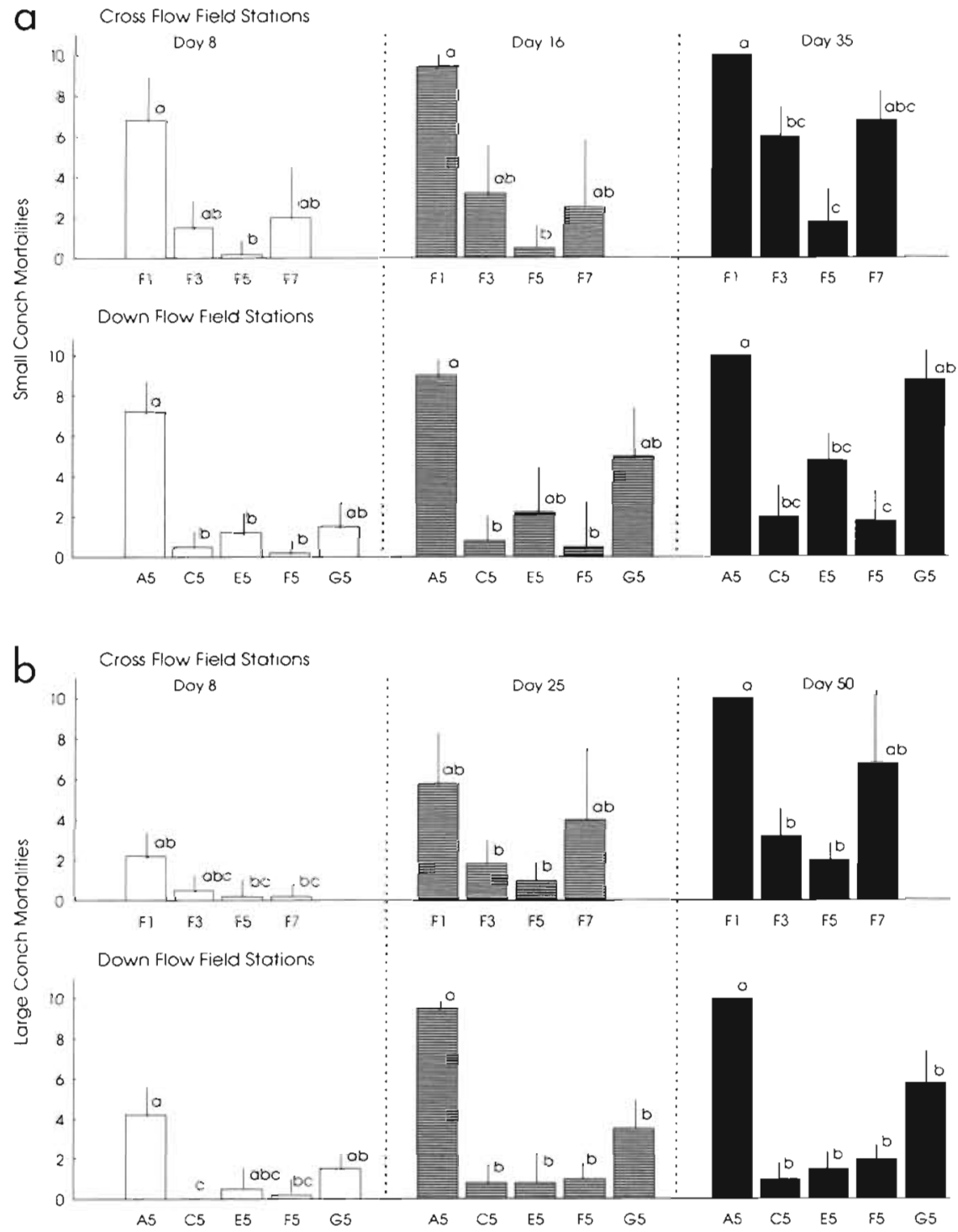

greater than that observed in conch on bare sand, but the difference was not significant. However, during the second period, growth rates peaked at Stn F7. Growth was also variable in the down flow field dimension, through moderate density seagrass.

Stepwise multiple regression with 4 independent variables (algae and Thalassia testudinum shoot count, detritus, and green biomass) explained little of the variation in growth during the first $5 \mathrm{wk}$ growth period. During the second growth period, green $T$. testudinum biomass showed a significant positive relationship with growth rate $\left(\mathrm{R}^{2}=0.559, \mathrm{p}=0.033\right)$.

Growth rates of conch at 2 stations outside the aggregation (Stns A5 \& E5) were not significantly different from those of conch at 2 stations inside the aggregation (Stns C5 \& F5). At another station outside the aggregation (Stn G5) growth rates were, however, consistently low $\left(0.036\right.$ to $\left.0.037 \mathrm{~mm} \mathrm{~d}^{-1}\right)$, never more than $1 / 3$ the growth rate of conch at all other stations except Stn F1, but not significantly different from 1 of the 2 stations inside the aggregation during each growth period.

Condition factors of conch in both flow field dimensions were not significantly different, except Stn A5 conch had higher condition factors than those at Stn F1 (Table 3). Mean gut fullness values, though subjective, paralleled the condition factor results.

\section{Tether experiments}

The mean number of dead conch per tether block at each station is shown by observation day in Fig. 3a (small conch) and Fig. 3b (large conch). Across the flow field gradient, from bare sand (Stn F1) to dense 
Table 3. Strombus gigas. Condition factor and gut fullness for enclosed conch at 8 stations. All values are mean $\pm S D(n=2)$. $F$ and $p$ values are for 1 -way ANOVA on homogeneous data (Cochran's test, $\mathrm{p}>0.05$ ). Means which were not different statistically are designated by similar lower-case letters (Tukey HSD multiple comparison test, $\mathrm{p}>0.05$ )

\begin{tabular}{|lcc|}
\hline Stn & Condition factor & Gut fullness \\
\hline A5 & $0.274 \pm 0.032 \mathrm{a}$ & $4.6 \pm 0.6 \mathrm{a}$ \\
C5 & $0.238 \pm 0.022 \mathrm{ab}$ & $4.2 \pm 0.5 \mathrm{a}$ \\
E5 & $0.237 \pm 0.018 \mathrm{ab}$ & $3.5 \pm 0.3 \mathrm{ab}$ \\
F5 & $0.233 \pm 0.016 \mathrm{ab}$ & $3.8 \pm 0.1 \mathrm{ab}$ \\
G5 & $0.189 \pm 0.030 \mathrm{ab}$ & $3.8 \pm 0.4 \mathrm{ab}$ \\
F1 & $0.176 \pm 0.025 \mathrm{~b}$ & $2.4 \pm 0.4 \mathrm{~b}$ \\
F3 & $0.240 \pm 0.013 \mathrm{ab}$ & $3.8 \pm 0.4 \mathrm{ab}$ \\
F7 & $0.242 \pm 0.011 \mathrm{ab}$ & $3.8 \pm 0.1 \mathrm{ab}$ \\
& $F(7,8)=4.039$ & $F(7,8)=5.141$ \\
& $p=0.034$ & $\mathrm{p}=0.017$ \\
\hline
\end{tabular}

seagrass (Stn F7), over half the small conch at Stn F1 were dead by Day 8, and none survived to Day 25. At Stns F5 \& C5, however, over half the small conch survived to the end of the experiment at Day 35. In the down flow field dimension, over half the small conch at Stn A5 were dead by Day 8 , a few were alive on Day 16 , but none survived to Day 35.

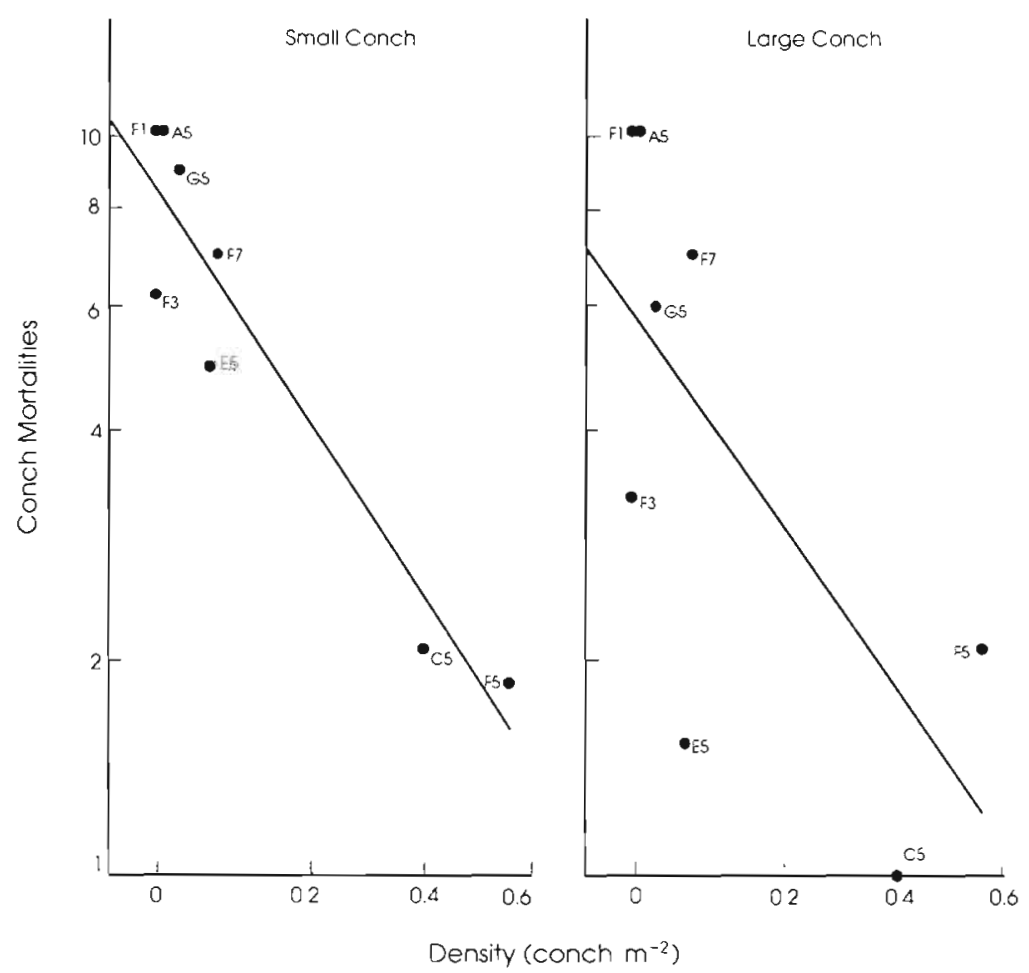

Fig. 4. Strombus gigas. Tethered conch mortality at 8 stations after $35 \mathrm{~d}$ (small conch) and $50 \mathrm{~d}$ (large conch) plotted as a function of wild conch density using log scales. For small conch, $y=-3.76 x+0.92$; for large conch, $y=-3.47 x+0.75$
Peaks in mortality occurred at Stns E5, A5 \& G5, stations which were outside the edges of the population boundaries (Fig. 1c). The latter 2 stations also had lower Thalassia testudinum density, green biomass, and detritus than the 2 stations inside the aggregation (Stns C5 \& F5). Although the large conch on bare sand at Stn F1 fared better than the small over time, none survived to Day 50 (Fig. 3b). Over half survived, however, at Stns F3 \& F5. All the large conch at Stn A5 were killed in $35 \mathrm{~d}$, while more than half were alive on Day 50 at Stns C5, E5 \& F5. The secondary peak in small conch mortality at Stn E5 was not observed in large conch, and station differences for the large conch were minimal except at Stns A5 \& F1 (Fig. 3a, b). Predation-induced mortality is known to decrease with increasing conch size as individuals reach a size refuge (Jory \& Iverson 1983, Appeldoorn 1984, Iverson et al. 1986).

Mortality was always significantly higher at Stn A5 than at Stns C5 \& F5 (Fig. 3a, b). The same was true for mortality at Stn F1 except in the large conch on Days 8 and 25. Again, Stns A5 \& F1 were located well outside the peripheries of the wild aggregation, and Stns C5 \& F5 were inside.

Wild conch density at the 8 stations accounted for most of the variation in tether mortality in both size classes, but moreso for small conch $\left(\mathrm{R}^{2}=0.890\right.$, $\mathrm{p}<0.001)$ than for large $\left(\mathrm{R}^{2}=0.452, \mathrm{p}=\right.$ 0.068 ) [variables were $\log _{10}$ (mortality) and $\log _{10}$ (density +1 )] (Fig. 4). Using conch density and Thalassia testudinum detritus, green biomass and shoot counts as independent variables, stepwise multiple regression showed that mortality of both size classes was significantly correlated only with conch density, and the correlation was negative.

In the 1992 tether experiment we reexamined mortality at Stns A5 (where wild conch density was $\leq 0.01$ in both 1991 and 1992) and F5 (where wild conch density had decreased from 0.56 conch $\mathrm{m}^{-2}$ in 1991 to 0.09 in 1992). Small conch at Stn F5 were killed at a higher rate in 1992 than in 1991 on each of the 4 observation days ( $t$-tests on arcsinetransformed, homogeneous data; $p<0.03$ for all 4 comparisons) (Fig. 5). At Stn A5, mortality was higher in 1992 on Days 8 $\& 16$ ( $p<0.04$ in both cases), but there was no difference by Day 25. By Day 35 . there were only 3 live conch left at Stn A5 in 1992 and none in 1991. 
Fig. 5. Strombus gigas. Number of small conch killed per block of 10 at 2 different stations after a substantial decrease in wild conch density at $\operatorname{Stn} F 5$, which was located inside the wild aggregation in May 1991 and outside it in May 1992. Stn A5 was outside the aggregation both years. Values are mean $\pm \operatorname{SE}(n=4)$

At most stations for which data were available, average growth for tethered conch of both sizes was ca $0.1 \mathrm{~mm} \mathrm{~d}^{-1}$ (Table 4). There are no growth data from Stns A5 \& F1 because all conch were killed by the end of the tethering experiment. Growth rates for both size classes were highest at Stns F3 \& F5 and lowest at Stns F7 \& G5. Although data were not designed for a statistical comparison between large tethered conch and caged conch, inspection of the means suggests an unusual difference at station Stn F7, where conch growth in cages was high but low on tethers. There were no significant differences in condition factor of small conch among stations. In the larger size class, condition factor was low at Stn $\mathrm{F} 7$.

The density survey of wild conch and suspected conch predators showed high hermit crab densities at Stn C5 $\left(0.76 \mathrm{~m}^{-2}\right)$ but low densities at Stn F5 (0.02 $\left.\mathrm{m}^{-2}\right)$. the other station inside the aggregation (Table 2). Apple murex densities were low $\left(\leq 0.02 \mathrm{~m}^{-2}\right)$ at every station. Motile predators such as crabs and lobsters also occurred in the area; these were not quantified. Although only 1 tulip snail, at Stn E5, was encountered during the quantified density survey, this carnivorous species was an important predator during this study. Individuals were observed attacking small tethered conch on 3 separate occasions at Stns F3, F7 \& G5, large tethered conch on 2 separate occasions at Stn F1, and caged conch through the wire mesh at Stn F1.

Tethered shells that were hardly damaged or only chipped along the growing edge (ca $62 \%$ of small killed conch and ca $41 \%$ of large killed conch) could have been killed by tulip snails or hermit crabs. Species of Fasciolaria lack a drill apparatus and overcome prey using forceful introduction of the proboscis and radula (Wells 1958). leaving an undamaged shell (Jory 1982).

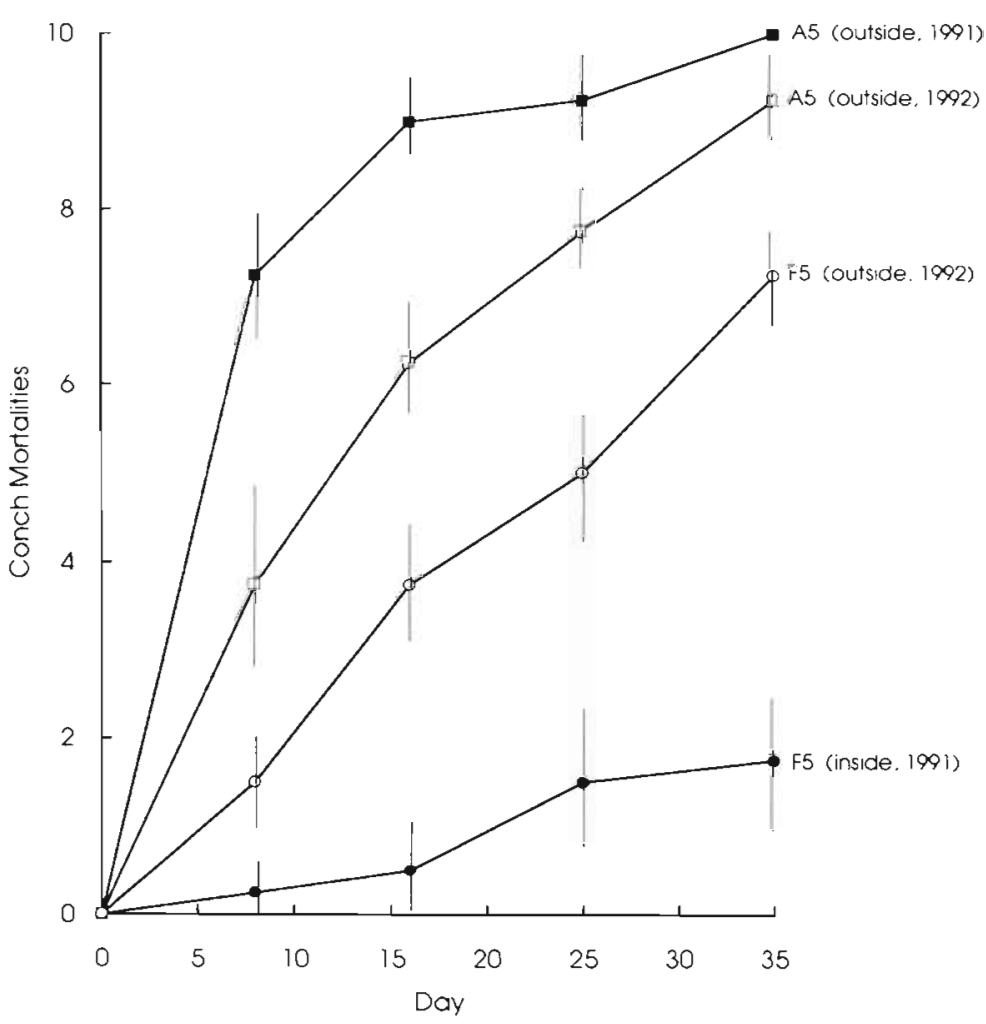

Table 4. Strombus gigas. Growth rates, condition factor, and gut fullness for small and large tethered conch. Values are mean $\pm S D(n)$; $n$ for gutfullness is the same as for condition factor. Fand $p$ values are for 1-way ANOVA (Cochran's test for homogeneity: $p>0.05$ in all comparisons except small conch condition factor where $0.01<p<0.05$ ). Means that were not different statistically are designated by similar lower-case letters (Tukey HSD multiple comparison test, $p>0.05$ )

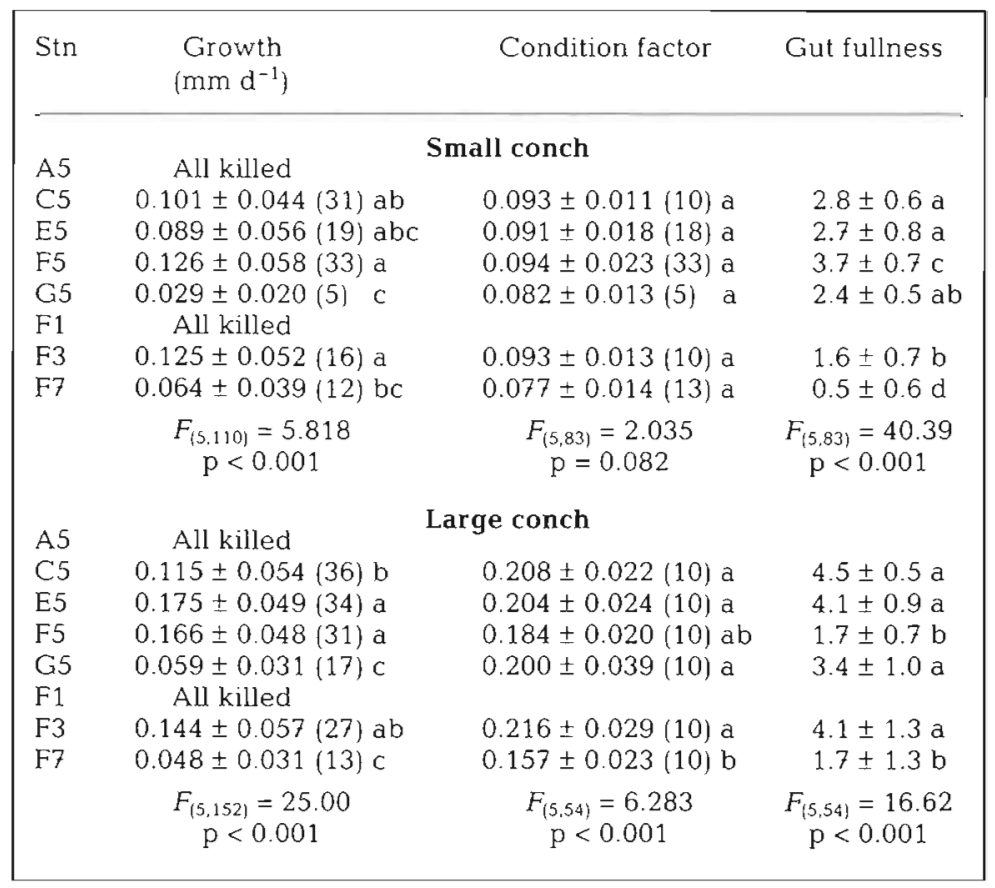


Hermit crabs can also kill conch without damaging the shell, though Jory (1982) speculated that they were not as frequent a predator as tulip snails in the Berry Islands, Bahamas. Although $96 \%$ of the dead tethered conch remaining at the end of the experiments were occupied by hermit crabs, hermit crabs were not necessarily the predators.

A portunid crab was observed feeding on a large tethered conch at Stn F1, and the apertures of 7 small conch (from Stns A5, E5, F1 \& F5) had several mm of shell aperture peeled back along the spire. This type of shell damage is typical of that inflicted by spiny lobster (Randall 1964, Vermeij 1978, Davis 1992) and crabs of the genus Calappa (Vermeij 1982). Several small shells and a few large ones had a large piece removed from the aperture, and 8 large conch at Stn A5 were found lacking opercula while still alive. No conch shells were observed with drilled holes, which are made by octopods or muricid gastropods (Jory \& Iverson 1983). Crushed shells were found only rarely around those tethers without shells, suggesting that most of the shells which were gone completely (ca 18\% small killed conch and ca $19 \%$ large killed conch) had been cut from their lines and carried away by large, motile predators.

Table 5 summarizes relative mortality, growth rates, and availability of alternative prey at each of the 8 stations.

\section{DISCUSSION}

\section{Habitat effects on conch growth}

Enclosure experiments showed that seagrass characteristics are poor predictors of habitat suitability for juvenile queen conch growth. In areas unoccupied by conch, both high and low growth rates have been observed in moderate density Thalassia testudinum (Stoner \& Sandt 1991), while high growth rates have been found in areas of low and low-moderate Thalassia testudinum density (this study, Stns F3 \& A5). In fact, conch grew at a rate $>0.1 \mathrm{~mm} \mathrm{~d}^{-1}$ at every station in the Shark Rock flow field except on bare sand (Stn F1) and at the western-most station (Stn G5). Condition factor and gut fullness were similar among all 8 stations except between Stns A5 and F1. Juvenile queen conch apparently occupy only portions of the nutritionally-suitable seagrass habitat available, and factors relating to predation appear to play a more influential role in their distribution.

\section{Habitat effects on conch survivorship}

Juvenile queen conch can discern and choose among different habitats. They actively select moderate density seagrass over bare sand and over both low and high density seagrass (Stoner \& Waite 1990). Structurally complex habitats generally harbor higher animal densities than non-vegetated areas (Cooper \& Crowder 1979, Heck et al. 1989, Schneider \& Mann 1991), though predation may (Gotceitas \& Colgan 1989) or may not (Nelson \& Bonsdorff 1990, Worthington et al. 1992) reach a threshold at increased habitat complexity.

In this study, mortality across the flow field gradient was high on bare sand, minimal in moderate seagrass biomass, and similar between high seagrass biomass and bare sand, suggesting a non-linear relationship between survivorship and seagrass structure rather than a linear relationship and a threshold at a certain

Table 5. Strombus gigas tethered and caged in Thalassia testudinum. Summary at 8 stations of seagrass shoot density and green biomass, mortality in small and large conch tethering experiments, growth of enclosed conch during 2 consecutive 5 wk periods, and the presence or absence of alternative prey [based on wild conch (60 to $109 \mathrm{~mm}$ ) found during the density survey]. The terms low, medium, and high are relative, representing the range observed in this study. Stn F5 data are given twice for comparison in both flow field dimensions

\begin{tabular}{|c|c|c|c|c|c|}
\hline Stn & Shoots & Green & $\begin{array}{l}\text { Relative } \\
\text { mortality }\end{array}$ & $\begin{array}{l}\text { Relative } \\
\text { growth }\end{array}$ & $\begin{array}{c}\text { Alternative } \\
\text { prey }\end{array}$ \\
\hline \multicolumn{6}{|c|}{ Down flow field (northeast to southwest) } \\
\hline A5 & Moderate & Low to moderate & High & Moderate to high & No \\
\hline C5 & Moderate to high & Moderate & Low & Moderate to high & Yes \\
\hline E5 & Moderate & Moderate & Low to moderate & Moderate & Yes \\
\hline F5 & Moderate to high & Moderate & Low & Moderate & Yes \\
\hline G5 & Low to moderate & Low to moderate & Moderate to high & Low & Yes \\
\hline \multicolumn{6}{|c|}{ Cross flow field (south to north) } \\
\hline F1 & Very low & Very low & High & Low & No \\
\hline F3 & Low & Low to moderate & Moderate & Moderate to high & No \\
\hline F5 & Moderate to high & Moderate & Low & Moderate & Yes \\
\hline F7 & Moderate to high & High & Moderate to high & Moderate to high & No \\
\hline
\end{tabular}


degree of habitat structure. Juvenile blue crabs were shown to survive best at intermediate levels of complexity because their burial escape response was inhibited by high densities of eelgrass (Wilson et al. 1987), and young conch may be hampered by high levels of seagrass structure in their efforts to move away from predators (Randall 1964, Stoner \& Waite 1990, Marshall 1992).

High density seagrass and detritus may also harbor high densities of predators. As in the case with high abundances of ophiuroids (Aronson 1989), juvenile conch may be inhabiting certain areas because they are relatively free of predators. However, this is unlikely, given the presence of tulip snails, hermit crabs, and highly motile predators such as sharks and lobsters (Marshall 1992; see also Table 2) and the relative uniformity of habitat down the flow field.

It may be argued that conch tethered at Stn F7, where Thalassia testudinum biomass was highest, were at a nutritional disadvantage compared with enclosed conch at the same station because conch growth rates on tethers were relatively low 10.05 to 0.06 vs 0.12 to $0.20 \mathrm{~mm} \mathrm{~d}^{-1}$ ). However, tethered conch clearly did not starve, and this dissimilarity points to the importance of combining different experimental methods in evaluating habitat quality.

Only in the down flow field dimension can mortality be examined relatively independently of seagrass density, although high mortality at the extreme stations, Stns A5 \& G5, may partially reflect their low-moderate Thalassia testudinum shoot density, green biomass, and detritus, compared with higher values at Stns C5 \& F5. Nevertheless, any relationship between mortality and seagrass structure in both dimensions was driven by conch density.

\section{Density-dependent effects}

The correlation between wild conch density and proportional mortality on tethers was negative and highly significant. Mortalities were highest at no-conch Stns F1 \& A5, and lowest at the 2 stations inside the aggregation. Individuals outside the aggregation were clearly at a disadvantage, although being beyond but close to the aggregation may have conferred some benefit. For example, mortality at a third no-conch station, Stn F3, was lower than at either Stns F1 or A.5, probably because Stn F3 was physically closer to a high density conch area. Similarly, Marshall (1992) found tethered conch mortality to be low inside 2 different aggregations and high $350 \mathrm{~m}$ outside them, but results were variable with conch tethered only $50 \mathrm{~m}$ from the aggregation. Furthermore, densitydependence in predation rate was shown by the sig- nificant increase in mortality between 1991 and 1992 at Stn F5, from which the conch aggregation disappeared over the year. Not surprisingly, mortality remained the same at $\mathrm{Stn} \mathrm{A} 5$, where resident conch were never abundant.

Our results suggest that conch gain safety in numbers, i.e. the probability of being preyed upon is inversely related to the number of alternative prey available. Although relatively slow-moving animals, conch are capable of escaping predators by 'leaping' away on their opercula. Alternatively, clam species, with low mobility, exhibit low-density refuges (Boulding \& Hay 1984, Sponaugle \& Lawton 1990, Mansour \& Lipcius 1991). Reduced predator foraging efficiency at low prey density, substrate type and heterogeneity, and different behaviors shown by different predators are factors affecting mortality of these sedentary bivalves (Sponaugle \& Lawton 1990), and variation in response to predation clearly exists among molluscs.

Catterall \& Poiner (1983) found intraspecific attraction to be an important factor in mediating distribution of Strombus luhuanus which, like S. gigas, also occupies only portions of broad areas of suitable habitat. A prey species may choose safer conditions (i.e. shelter in the form of vegetation or conspecifics), in which food is less abundant, over a more 'profitable', but less safe situation, compromising maximum feeding and growth rates for reduced risk of predation (Folt 1987, Werner \& Hall 1988). Mussels living in relatively large clumps exhibit both lower growth rates and lower mortality than those living in smaller clumps (Lin 1989a, b). Conch also exhibit low growth at very high densities (4 to 8 conch $\mathrm{m}^{-2}$; Stoner 1989), though in this study, conch enclosed at a density of $1 \mathrm{~m}^{-2}$ at the 2 stations inside the aggregation did not sacrifice growth rates, which were comparable to some stations outside the aggregation. Tethered conch, however, clearly gained an advantage by being surrounded by other conch, suggesting that conch achieve a balance between growth and survivorship.

\section{CONCLUSIONS}

Juvenile conch distribution is influenced by complex interactions between intraspecific competition (i.e. density-dependent decreases in growth shown by Stoner 1989) and density-dependent increases in survivorship (Marshall 1992, this study). Although individuals may exhibit high growth rates when separated from conspecifics and not subject to competition for food, predation will most certainly be higher. Large-scale distribution of conch nurseries appears to be determined by food productivity, physical characteristics (sediment, distance from inlets and sand bars, 
depth, etc.), and the physical processes affecting them (wind, tides, current) (Stoner et al. 1993), while smallscale distribution is greatly influenced by densitydependent phenomena including aggregation and predation

Acknowledgements. We are grateful to R. Gomez, J. Lally, D. Mansfield, and K. Schwarte for their work in the field. R. S. Appeldoorn, K. Brown, K. Heck, L. Marshall, and 3 anonymous reviewers gave insightful comments on the manuscript. Funding for this research was provided by a grant from the National Undersea Research Program, NOAA, U.S. Department of Commerce

\section{LITERATURE CITED}

Appeldoorn, R. S. (1984). The effect of size on mortality of small juvenile conchs (Strombus gigas Linne and S. costatus Gmelin). J. Shellfish Res. 4: 37-43

Aronson, R. B. (1989). Brittlestar beds: low-predation anachronisms in the British Isles. Ecology 70: 856-865

Barshaw, D. E., Able, K. W. (1990). Tethering as a technique for assessing predation rates in different habitats: an evaluation using juvenile lobsters Homarus americanus. Fish. Bull. U.S. 88: 415-417

Bell, J. D., Steffe, A. S., Westoby, M. (1988) Location of seagrass beds in estuaries: effects on associated fish and decapods. J. exp. mar. Biol. Ecol. 122: 127-146

Bell, J. D., Westoby, M. (1986). Abundance of macrofauna in dense seagrass is due to habitat preference, not predation. Oecologia 68: 205-209

Bertram, B. C. (1978). Living in groups: predators and prey. In: Krebs, J. R., Davies, N. B. (eds.) Behavioural ecology an evolutionary approach. Blackwell Scientific Publ., Oxford, p. 64-96

Boulding, E. G., Hay, T K. (1984). Crab response to prey density can result in density-dependent mortality of clams. Can. J. Fish. Aquat. Sci. 41: 521-525

Catterall, C. P., Poiner, I. R. (1983). Age- and sex-dependent patterns of aggregation in the tropical gastropod Strombus luhuanus. Mar. Biol. 77: 171-182

Cooper, W. E., Crowder, L. E. (1979). Patterns of predation in simple and complex environments. In: Shoud, R. H., Clopper, $H$. (eds.) Predator prey systems in fisheries management. Sport Fishing Institute, Washington, DC, p. 257-267

Davis, M. (1992). Predation of hatchery-reared juvenile queen conch, Strombus gigas (L.) by juvenile spiny labsters, Panulirus argus (L.). M.Sc. thesis, Florida Inst. of Technology, Melbourne

Day, R. W., Quinn, G. P. (1989). Comparisons of treatments after an analysis of variance in ecology. Ecol. Monogr. 59 : $433-463$

Folk, R. L. (1966). A review of grain-size parameters. Sedimentology 6: 73-93

Folt, C. L. (1987). Experimental analysis of costs and benefits of zooplankton aggregation. In: Kerfoot, W. C., Sih, A. (eds.) Predation. University Press of New England, London, p. 300-314

Gotceitas, V., Colgan, P. (1989). Predator foraging success and habitat complexity: quantitative test of the threshold hypothesis. Oecologia 80: 158-166

Hager, M. C., Helfman, G. S. (1991). Safety in numbers: shoal size choice by minnows under predatory threat. Behav. Ecol. Sociobiol, 29: 271-276
Heck, K. L. Jr, Able, K. W., Fahay, M. P., Roman, C. T (1989), Fishes and decapod crustaceans of Cape Cod eelgrass meadows: species composition, seasonal abundance patterns and comparison with unvegetated substrates. Estuaries 12: 59-65

Heck, K. L. Jr, Thoman, T. A. (1981). Experiments on predator-prey interactions in vegetated aquatic habitats. J. exp. mar. Biol. Ecol. 53: 125-134

Heck, K. L. Jr, Wilson, K. A. (1987). Predation rates on decapod crustaceans in latitudinally separated seagrass communities: a study of spatial and temporal variation using tethering techniques. J. exp. mar. Biol. Ecol. 107: 87-100

Howard, R. K., Edgar, G. J., Hutchings, P. A. (1989). Faunal assemblages of seagrass beds. In: Larkum, A. W. D., McComb, A. J., Shepherd, S. A. (eds.) Biology of seagrasses. II. Elsevier, Amsterdam, p. 536-564

Hurlbert, H. S. (1984). Pseudoreplication and the design of ecological field experiments. Ecol. Monogr. 54: 187-211

Iverson, E. S., Jory, D. E., Bannerot, S. P. (1986). Predation on queen conchs, Strombus gigas, in the Bahamas. Bull mar. Sci. 39: 61-75

Jory, D. E. (1982). Predation by tulip snails, Fasciolaria tulipa, on queen conchs, Strombus gigas. M.Sc. thesis, Univ. of Miami, Coral Gables

Jory, D. E., Iverson, E. S. (1983). Queen conch predators: not a roadblock to mariculture. Proc. Gulf Caribb. Fish. Inst. 35 $108-111$

Livingston, R. J. (1984). Trophic response of fishes to habitat variability in coastal seagrass systems. Ecology 65 $1258-1275$

Lin, J. (1989a). Importance of location in the salt marsh and clump size on growth of ribbed mussels. J. exp. mar. Biol. Ecol. 128: 75-86

Lin, J. (1989b). Influence of location in a salt marsh on survivorship of ribbed mussels. Mar. Ecol. Prog. Ser. 56 . 105-110

Mansour, R. A., Lipcius, R. N. (1991). Density-dependent foraging and mutual interference in blue crabs preying upon infaunal clams. Mar. Ecol. Prog. Ser. 72: 239-246

Marshall, L. S. (1992). Survival of juvenile queen conch, Strombus gigas, in natural habitats: impact of prey, predator and habitat features. Ph.D. thesis, College of William and Mary, Williamsburg, VA

McBride, E. F. (1971). Mathematical treatment of size distribution data. In: Carver, R. E. (ed.) Procedures in sedimentary petrology. Wiley, New York, p. 109-127

Nelson, W. G., Bonsdorff, E. (1990). Fish predation and habitat complexity: are complexity thresholds real? J. exp. mar. Biol. Ecol. 141.183-194

Orth, R. J., Heck, K. L. Jr, van Montfrans, J. (1984). Faunal communities in seagrass beds: a review of the influence of plant structure and prey characteristics on predator-prey relationships. Estuaries 7: 339-350

Pohle, D. G., Bricelj, V. M., Garcia-Esquivel, Z. (1991). The eelgrass canopy: an above-bottom refuge from benthic predators for juvenile bay scallops Argopecten irradians. Mar. Ecol. Prog. Ser. 74: 47-59

Pulliam, H. R., Caraco, T (1984). Living in groups: is there an optimal group size? In: Krebs, J. R., Davies, N. B. (eds.) Behavioural ecology an evolutionary approach, 2nd edn. Sinauer Associates, Sunderland, MA, p. 122-147

Randall, J. E. (1964). Contributions to the biology of the queen conch, Strombus gigas. Bull mar. Sci. Gulf. Caribb. 14: 246-295

Schneider, F. I., Mann, K. H. (1991). Species specific relationships of invertebrates to vegetation in a seagrass bed. I. Correlational studies. J. exp. mar. Biol. Ecol. 145: 101-117 
Smith, K. N., Herrnkind, W. F. (1992). Predation on early juvenile spiny lobsters Panulirus argus (Latreille): influence of size and shelter. J. exp. mar. Biol. Ecol. 157: 3-18

Sokal, R. R., Rohlf, F. J. (1981). Biometry. W. H. Freeman and Company, New York

Sponaugle, S., Lawton, P. (1990). Portunid crab predation on juvenile hard clams: effects of substrate type and prey density. Mar. Ecol. Prog. Ser. 67: 43-53

Stoner, A. W. (1989). Density-dependent growth and grazing effects of juvenile queen conch Strombus gigas L. in a tropical seagrass meadow. J. exp. mar. Biol. Ecol. 130: $119-133$

Stoner, A. W., Davis, M. (1994). Experimental outplanting of juvenile queen conch, Strombus gigas: comparison of wild and hatchery-reared stocks. Fish. Bull. U.S. (in press)

Stoner, A. W., Hanisak, M. D., Smith, N. P., Armstrong, R. A. (1993). Large-scale distribution of queen conch nursery habitats: implications for stock enhancement. In: Appeldoorn, R. S., Rodriguez, B. (eds.) Queen conch biology, fisheries, and mariculture. Fundación Cientifica Los Roques, Caracas (in press)

Stoner, A. W., Lewis, F. G. III (1985). The influence of quantitative and qualitative aspects of habitat complexity in tropical sea-grass meadows. J. exp. mar. Biol. Ecol. 94: 19-40

Stoner, A. W., Ray, M. (1993). Aggregation dynamics in juvenile queen conch: population structure, mortality, growth, and migration. Mar. Biol. 116: 571-582

Stoner, A. W., Sandt, V. J. (1991). Experimental analysis of habitat quality for juvenile queen conch in seagrass meadows. Fish. Bull. U.S. 89: 693-700

This article was presented by K. L. Heck Jr, Dauphin Island, Alabama, USA
Stoner, A. W., Waite, J. M. (1990). Distribution and behavior of queen conch, Strombus gigas, relative to seagrass standing crop. Fish. Bull. U.S. 88: 573-585

Stoner, A. W., Waite, J. M. (1991). Trophic biology of Strombus gigas in nursery habitats: diets and food sources in seagrass meadows j. mollusc. Stud 57: 451-460

Vermeij, G. J. (1978). Biogeography and adaptation: patterns of marine life. Harvard University Press, Cambridge

Vermeij, G. J. (1982). Gastropod shell form, breakage, and repair in relation to predation by the crab Calappa. Malacologia 23: 1-12

Wells, H. W (1958). Predation of pelecypods and gastropods by Fasciolari hunteria (Perry). Bull. mar. Sci. 8: 152-165

Werner, E. E., Hall, D. J. (1988). Ontogenetic habitat shifts in bluegill: the foraging rate - predation risk trade-off. Ecology 69: 1352-1366

Wicklund, R. I., Hepp, L. J., Wenz, G. A. (1991). Preliminary studies on the early life history of the queen conch, Strombus gigas, in the Exuma Cays, Bahamas. Proc. Gulf. Caribb. Fish. Inst. 40: 283-298

Wilson, K. A. Able, K. W., Heck, K. L. Jr (1990). Predation rates on juvenile blue crabs in estuarine nursery habitats: evidence for the importance of macroalgae (Ulva lactuca). Mar. Ecol. Prog. Ser. 58: 243-251

Wilson, K. A., Heck, K. L. Jr, Able, K. W. (1987). Juvenile blue crab, Callinectes sapidus, survival: an evaluation of eelgrass, Zostera marina, as refuge. Fish. Bull. U.S. 85: 53-58

Worthington, D. G., Ferrell, D. J., McNeill, S. E., Bell, J. D. (1992). Effects of the shoot density of seagrass on fish and decapods: are correlation evident over larger spatial scales? Mar. Biol. 112: 139-146

Manuscript first received: July 29, 1993

Revised version accepted: November 10, 1993 